controls) of IL- 2 positive cells; 6 patients and 1 control of IL-4 positive cells and 7 patients and 0 control of IFN- $\gamma$ positive cells. Six patients presented increased percentages of both IL-2 and IL4 and IFN- $\gamma$ (i.e. they had both Th1 and Th2 activation), 4 of IL- 2 positive cells and 1 IFN- $\gamma$ only (isolated Th1 activation).

After PMA stimulation 6 patients presented increased percentages of IFN- $\gamma$ positive cells; 1 of IL- 4 and 0 patient of IL- 2 positive cells.

Conclusion Our study demonstrates that Th1 activation occurs in peripheral blood of SSc patients. The role, if any, of such activation must be investigated.

\section{OP0040 BUCILLAMINE AND ITS METABOLITES INDUCE SYNTHESIS OF VEGF DOSE DEPENDENTLY IN SYSTEMIC SCLEROSIS FIBROBLASTS VIA THE NF-KB PATHWAY}

${ }^{1} \mathrm{C}$ Hagen, ${ }^{1} \mathrm{O}$ Distler, ${ }^{2} \mathrm{U}$ Müller-Ladner, ${ }^{3} \mathrm{~A}$ Carossino, ${ }^{1} \mathrm{RE}$ Gay, ${ }^{4} \mathrm{R}$ Nanagara, ${ }^{5} \mathrm{BA}$ Michel, ${ }^{6} \mathrm{~K}$ Nishioka, ${ }^{3} \mathrm{M}$ Matucci-Cerinic, 'S Gay. ${ }^{1} \mathrm{Ctr}$ Exp Rheum; ${ }^{2}$ Department Int Medicine I, University Hospital, Regensburg, Germany; ${ }^{3}$ Department Medicion Sect. Rheum., University Hospital, Florence, Italy; ${ }^{4}$ Department Rheum, University Hospital, KhonKaen, Thailand; ${ }^{5}$ Department Rheum, University Hospital, Zurich, Switzerland; ${ }^{6}$ Institute Medicine Science, St Marianna University, Kanagawa, Japan

\subsection{6/annrheumdis-2001.297}

Background Bucillamine (BUC) is an immunomodulatory drug used in the treatment of rheumatoid arthritis with inhibitory effects on B- and T-cell functions. However, the impact of Bucillamine on metabolic pathways of fibroblasts has not been addressed.

Objectives Since an altered metabolism of fibroblasts is a hallmark of systemic sclerosis (SSc), we investigated whether BUC and its metabolites SA981 and SA679 influence the cytokine pattern of skin fibroblasts and might be of therapeutical use in SSc. Methods Cultures of skin fibroblasts from 6 patients with SSc and 5 healthy controls were incubated with BUC, SA981 and SA679 at different concentrations for 6 to $24 \mathrm{~h}$. Quantification for VEGF, IL-6 and TGF-b1 mRNA was performed with realtime PCR (TaqMan). Supernatants were analysed for VEGF by ELISA. In addition, fibroblasts were preincubated with the NF$\mathrm{kB}$ inhibitor pyrrolidine dithiocarbamate (PDTC) and analysed for the expression of VEGF as describe above. The trypan blue dye exclusion test was used to assess the viability of the cells. The effects on the chemotactic activity of fibroblasts were examined in a modified Boyden chamber assay.

Results VEGF mRNA was increased in all fibroblast cultures after BUC treatment compared to non-treated controls, whereas no effect was observed on the levels of IL- 6 and TGF-b1. VEGF mRNA increased dose dependently with both BUC and its metabolites. The most significant induction was observed after treatment with SA981 $(1 \mathrm{mg} / \mathrm{ml}: 7.7 \pm 4.3,0,6 \mathrm{mg} / \mathrm{ml}: 5.2 \pm$ $2.3 ; 0,15 \mathrm{mg} / \mathrm{ml}: 2.9 \pm 1.4,0,05 \mathrm{mg} / \mathrm{ml}: 2.5 \pm 1.9$ fold increase, $\mathrm{p}<0.05)$. Fibroblast cultures from patients with SSc showed a consistent higher inducibility of VEGF than cultures from healthy controls (SSc: $9.9 \pm 4.3$; healthy controls: $5.2 \pm$ 2.8 fold increase, $\mathrm{p}<0.05)$. These results were confirmed on the protein level with a significant rise of VEGF in SSc cultures, but not in healthy controls. The increase of VEGF was not due to unspecific toxicity, since the cell viability was $>95 \%$ in treated and non-treated fibroblasts. Preincubation with the NF$\mathrm{kB}$ inhibitor PDTC reduced the production of VEGF by $60 \%$. Interestingly, there was a significant increase in the chemotactic activity of supernatants from fibroblasts treated with BUC (133 \pm 39 cells/high power field $=$ hpf $)$, SA679 $(72 \pm 19$ cells $/$ hpf $)$ and SA981 (43 \pm 5 cells/hpf) compared to non-treated controls (26 \pm 7 cells/hpf).

Conclusion Our results indicate that BUC and its metabolites, in addition to the known immunomodulatory effects, may have favourable influence on neoangiogenesis in SSc through the release of VEGF by skin fibroblasts. Since impaired angiogenesis and inflammatory infiltrates are hallmarks in the pathogenesis of $\mathrm{SSc}$, BUC may be of benefit in the treatment of this disease.

\section{OP0041 ESOPHAGEAL MANOMETRY FINDINGS IN PATIENTS WITH RAYNAUD'S PHENOMENON AND POSITIVE ANTINUCLEAR ANTIBODIES}

'A Arteaga, 'E Trujillo, II Ferraz, 'A Alvarez-Pío, '1 Bethencourt, ' ${ }^{1} \mathrm{~F}$ Díaz-González, ${ }^{2} \mathrm{C}$ Casanova, ${ }^{1} \mathrm{~T}$ González, ${ }^{1} \mathrm{~S}$ Bustabad. ${ }^{1}$ Rheumatology; ${ }^{2}$ Digestive, Hospital Universitario de Canarias., La Laguna, España

\subsection{6/annrheumdis-2001.298}

\section{Background}

Objectives To study the esophageal manometry in patients with Raynaud's phenomenon and positive antinuclear antibodies (ANA) in the absence of esophageal, skin or internal organs manifestations.

Methods 14 patients, 13 women and 1 man (46,8 mean age; 965 years) with mean evolution time of Raynaud's henomenon of 5 years were included in this study. Nailfold capillary microscopy study, autoantibodies profile and esophageal manometry (Synetics Manometry Unid. Synetics neumocapillary Pump and Poligraph) were performed in all patients. The lower esophageal sphincter, esophageal body and upper esophageal sphincter pressures were analysed independently.

Results 44\% patients had a lower esophageal sphincter hipotonia which showed a significant relationship $(\mathrm{p}<0.05)$ with the presence of both articular disease (33.5\%) and anti-centromere antibodies (44.4\%). However, the naildfold scleroderma pattern (61\%) did not show a significant relationship with lower esophageal sphincter hipotonia. $33.3 \%$ patients showed unspecific motor alterations in the esophageal body. There was significant relationship $(\mathrm{p}<0.001)$ between esophageal body alterations and the naildfold scleroderma pattern. In all patients studied, the function of the upper esophageal sphincter was within the normal limits. In the control group of patients with Raynaud's phenomenon and negative ANA, the esophageal manometry was normal.

Conclusion Alterations in the esophageal manometry are frequent in patients with Raynaud`s phenomenon and positive ANA and they suggest the presence of systemic disease even in the absence of skin or internal organs involvement.

\section{OP0125 OVEREXPRESSION OF VASCULAR ENDOTHELIAL GROWTH FACTOR (VEGF) AND ITS RECEPTORS IN SYSTEMIC SCLEROSIS (SSC): EVIDENCE FOR PROTECTIVE EFFECTS OF VEGF AGAINST THE DEVELOPMENT OF FINGERTIP ULCERS}

${ }^{1} \mathrm{O}$ Distler, ${ }^{2} \mathrm{~A}$ Del Rosso, ${ }^{3} \mathrm{~A}$ Scheid, ${ }^{1} \mathrm{~J}$ Rethage, ${ }^{1} \mathrm{M}$ Neidhart, ${ }^{2} \mathrm{~A}$ Carossino, ${ }^{1} \mathrm{RE}$ Gay, ${ }^{4} \mathrm{U}$ Müller-Ladner, ${ }^{5} \mathrm{BA}$ Michel, ${ }^{3} \mathrm{M}$ Gassmann, ${ }^{2} \mathrm{M}$ Matucii-Cerinic, ${ }^{1} \mathrm{~S}$ Gay. ${ }^{1} \mathrm{C}$ tr Exp Rheum; ${ }^{2}$ Department Medicine Sect Rheum, University Hospital, Florence, Italy; ${ }^{3}$ Institute of Physiology: ${ }^{4}$ Department of Internal Medicine I, University Hospital, Regensburg, Germany; ${ }^{5}$ Department Rheumatology, University Hospital, Zurich, Switzerland

10.1136/annrheumdis-2001.299 
Background Vascular changes are consistent early findings in SSc and often proceed the development of fibrosis. Despite a severe reduction in the capillary density, signs of neoangiogenesis cannot be detected.

Objectives To examine the role of VEGF and its receptors in the impaired angiogenesis of SSc.

Methods Skin pO2 was measured intradermally using the pO2 histograph in 13 patients with SSc and in 5 healthy controls. Cultured SSc and normal skin fibroblasts were exposed to hypoxia and analysed for VEGF mRNA by real-time PCR (TaqMan). Immunohistochemistry with anti-VEGF-Receptor-1 and antiVEGF-Receptor-2 antibodies was performed on skin biopsies of SSc patients and healthy controls. Serum samples of 47 patients with SSc and 21 healthy controls were analysed for VEGF by ELISA and correlated with clinical parameters.

Results PO2 values from involved skin of SSc patients $(23,7 \pm$ $2,1 \mathrm{mmHg}$ ) were significantly lower compared to healthy controls $(33,6 \pm 4,1 \mathrm{mmHg})$ and non-involved skin areas $(37,8 \pm$ $8,6 \mathrm{mmHg}, \mathrm{p}<0.05)$. After hypoxic exposure of cultured fibroblasts, VEGF mRNA was found to be upregulated compared to normoxic controls in SSc (3,7 $\pm 1,7$ fold) and normal skin fibroblasts $(3,0 \pm 1,8$ fold). The bioavailability of VEGF was not reduced, since the expression of VEGF-Receptor-1 and VEGFReceptor- 2 was found on endothelial cells of $4 / 5$ patients with SSc, whereas no signal could be detected in healthy controls. In addition to the overexpression of VEGF mRNA in skin samples, serum levels of VEGF protein were significantly higher in SSc patients compared to healthy controls (mean $461 \mathrm{pg} / \mathrm{ml}$, range 93-1153 pg/ml vs. $106 \mathrm{pg} / \mathrm{ml}$, range $0-500 \mathrm{pg} / \mathrm{ml}, \mathrm{p}<0.001)$. Interestingly, levels of VEGF were upregulated in patients with pre-SSc (clinical evidence for SSc without fulfilling ACR criteria, mean $451 \mathrm{pg} / \mathrm{ml}$, range $230-601 \mathrm{pg} / \mathrm{ml}, \mathrm{p}<0.05)$ and in patients with early disease stages (disease duration $<2$ years, mean $569 \mathrm{pg} / \mathrm{ml}$, range $135-1013 \mathrm{pg} / \mathrm{ml}, \mathrm{p}<0.01$ ). Patients with diffuse disease and the presence of fingertip ulcers had higher levels of VEGF (mean $339 \mathrm{pg} / \mathrm{ml}$, range 93-714 pg/ml) than healthy controls, but highly significant lower levels than patients without fingertip ulcers (mean 655 pg/ml, range 281$1151 \mathrm{pg} / \mathrm{ml}, \mathrm{p}<0.001)$.

Conclusion Our results suggest a hypoxia mediated activation of the VEGF/VEGF-receptor axis in SSc. The correlation with clinical parameters indicate that elevated levels of VEGF are a feature of early disease stages and might be protective against the development of fingertip ulcers. Since the feasibility of a treatment with VEGF has just been approved in other ischaemic diseases, the application of VEGF may be a therapeutic option for the vascular insufficiency in SSc.

\section{Sjoegren's syndrome}

\section{AB0117 SALIVA IN PATIENTS WITH DIFFERENT RHEUMATIC DISEASES}

M Helenius, JH Meurman, I Helenius, K Kari, J Hietanen, R Suuronen, H Kautiainen, M Leirisalo-Repo, C Lindqvist. Department of Medicine, Meilahti Hospital, Helsinki, Finland

\subsection{6/annrheumdis-2001.300}

Background Rheumatic diseases affect salivary glands. ${ }^{1}$ However, data is sparse on saliva of patients with different disease subgroups with expected differencies.
Objectives We studied salivary flow and biochemistry in 22 patients with spondyloarthropathy (SPA), 19 with ankylosing spondylitis (AS), 25 with rheumatic arthritis (RA) and 19 with mixed connective tissue disease (MCTD) and 85 age- and sexmatched controls. The mean age was 44.5 years and duration of disease 10.5 years.

Methods Minor salivary gland biopsies were taken for inflammatory focus score, and salivary components analysed biochemically. $^{2}$

Results The results showed an inverse correlation between focus scores and decreased salivary flow rates $(\mathrm{R}=-0.48$, CI 0.64 0.29 for resting flow, $\mathrm{R}=-0.49$, CI $0.65-0.30$ for stimulated flow). Compared with controls, decreased resting flow $(<0.1$ $\mathrm{mL} / \mathrm{min})$ was most frequent in AS group $(22 \%$ vs. $0 \%, \mathrm{p}<$ $0.05)$, while decreased stimulated flow $(<0.7 \mathrm{~mL} / \mathrm{min})$ was most frequent in the MCTD group (60\% vs. $16 \%, \mathrm{p}<0.05)$. Lower concentrations of salivary amylase $(p<0.001)$, but higher albu$\min (\mathrm{p}<0.01)$, total protein $(\mathrm{p}<0.001), \operatorname{IgA}(\mathrm{p}<0.05), \operatorname{IgG}$ $(\mathrm{p}<0.001)$ and $\operatorname{IgM}(\mathrm{p}<0.001)$ were found in the patients.

Conclusion Thus, the hypothesis was confirmed showing significant differences in salivary parameters between patients and controls, and also differences between the patients with various rheumatic diseases.

\section{REFERENCES}

1 Daniels. Scand J Rheum. 1986;61:36-43

2 Pajukoski, et al. Oral Surg. 1997;84:265-71

\section{AB0118 SUPRA-NUCLEAR OPHTALMOPLEGIA IN PRIMARY SJÖGREN'S SYNDROME}

${ }^{1} \mathrm{~B}$ Mugnier, ${ }^{2} \mathrm{~F}$ Nicoli, ${ }^{1} \mathrm{JP}$ Mattei. ${ }^{1}$ Service de Rhumatologie; ${ }^{2}$ Centre de Résonance Magnétique Et Biologie Médicale, Faculté de La Timone, Marseille, France

10.1136/annrheumdis-2001.301

\section{Background}

Objectives Neurological manifestations involving the central and the peripheral nervous systems (CNS, PNS) are observed in $10 \%-32 \%$ of patients with primary Sjögren's syndrome (pSS). If the lesions of the PNS have been perfectly described, data on CNS involvement in pSS, as for it, is controversial with regard in significance and aetiology. On occasion of an exceptional supra-nuclear ophtalmoplegia during pSS, we discuss relevance of CNS involvement in pSS.

Methods

Results A 61 year-old-woman encompassed several episodes of neurologic involvement resolving completely without any treatment: twice it consisted of mied nerves involvement (dysphagia) and dysaesthesia in the trigeminal territories and four times of supra-nuclear ophtalmoplegia with typical palsy of volontary lateral and vertical gaze compensated for oculo-cephalics reflexes. Repeated cerebral investigations excluded multiple sclerosis and vascular lesions. The absence of hypertonia, akinesia, or frontal syndrome associated to opthtalmoplegia, despite several years duration, reduces the probability of a Steele-Richardson disease. Neurologic signs onset began sixteen years before the diagnosis of pSS (grade III histologic lesions on minor salivary gland biopsy). Biochemical, immunologic and histological investigations did not reveal any other connective tissue disorders.

This is the first case of supra-nuclear ophtalmoplegia developped in such a context. Oculo-motors troubles like nystagmus, ocular palsy, cerebellar syndrome and even internuclear ophtalmoplegia has been describe during pSS. Internuclear 